\title{
7. ve 8. Sınıf Öğrencilerinin Organ Bağışı ve Nakli Konusundaki Bilgi Düzeyleri ve Görüşlerinin İncelenmesi
}

\section{Examination of Knowledge Level and Opinions of 7th and 8th Grade Students on Organ Donation and Transplantation}

\author{
Ramazan SoĞUKPINAR ${ }^{* *}$ (iD) Dilek KARIŞAN ${ }^{* * *}$ (D) \\ Hilal AKTAMIŞ ${ }^{* * * *}$ (iD)
}

\begin{abstract}
Received: 24 April 2018
Research Article

Accepted: 27 May 2019

ABSTRACT: Despite the increase in the number of individuals donating organs in recent years, high numbers of individuals waiting for transplantation clearly demonstrates the importance of organ donation and organ transplantation. The aim of this study is to examine the knowledge level and opinions of 7th and 8th grade students on organ donation and transplantation. The research was conducted in the first semester of 2017-2018 academic year with 513 (264 girls, 249 boys) students from 7th and 8th grade who are studying in elementary school in Aydin, Kuyucak province. Convenient sampling was used in the study. The questionnaire consists of 12 questions developed by Akış et. al. (2008) and it aims to evaluate knowledge level and opinions of participants about organ donation. Descriptive analysis was employed for data analysis. Frequencies and percentages related to the data were calculated. Results show that there were differences between the 7th and 8th grade students in terms of knowledge level of organ donation and transplantation, but there was not much difference in terms of their views.
\end{abstract}

Keywords: organ transplantation, organ donation, primary school students, knowledge level.

ÖZ: Son yıllarda organlarını bağışlayan bireylerin sayısında artış olmasına rağmen organ nakli bekleyen bireylerin sayısının fazla olması organ bağışı ve organ nakli konusunun önemini açıkça göstermektedir. Çalışma ile 7 . ve 8 . sınıf öğrencilerinin organ bağışı ve organ nakline yönelik bilgi düzeyleri ve görüşlerinin incelenmesi amaçlanmıştır. Çalışmanın örneklemini 2017-2018 eğitim öğretim yılı birinci yarıyılında Aydın ili Kuyucak ilçesindeki devlet ortaokullarında öğrenim gören $513(264 \mathrm{~K}, 249$ E) 7. ve 8. sınıf öğrencileri oluşturmaktadır. Araştırmada uygun örnekleme yöntemi kullanılmıştır. Araştırmada veriler, Akış vd. (2008) tarafindan geliştirilen 12 sorudan oluşan organ bağışı bilgi düzeyi ve görüşleri anketi ile elde edilmiştir. Verilerin analizi betimsel olarak yapılmıştır. Verilere ilişkin frekanslar ve yüzdeler hesaplanarak analiz tabloları oluşturulmuştur. Çalışmada 7. ve 8. sınıf öğrencileri arasında organ bağışı ve nakli bilgi düzeyleri arasında farklar olduğu fakat görüşleri arasında çok fark olmadığ sonucu bulunmuştur.

Anahtar kelimeler: organ bağışı, organ nakli, ortaokul öğrencileri, bilgi düzeyi.

\footnotetext{
** Corresponding Author: Science Teacher, Ministry of Education, Aydin, Turkey, ramazansogukpinar68@gmail.com, https://orcid.org/0000-0003-4252-8930

Assoc. Prof. Dr., Adnan Menderes University, Aydın, Turkey, dilekkarisan@gmail.com, https://orcid.org/00000002-1791-9633

***** Prof. Dr., Adnan Menderes University, Aydın, Turkey, hilalaktamis@ gmail.com, https://orcid.org/0000-0003$0717-5770$
}

\section{Citation Information}

Soğukpınar, R., Karışan, D., \& Aktamış, H. (2019). 7. ve 8. sınıf öğrencilerinin organ bağışı ve nakli konusundaki bilgi düzeyleri ve görüşlerinin incelenmesi. Kuramsal Eğitimbilim Dergisi [Journal of Theoretical Educational Science], 12(3), 892-914. 


\section{Giriş}

Toplum ve bilim geçmişten günümüze birbiriyle etkileşim halinde bulunmuştur ve bu etkileşim hala sürmektedir (Topçu, 2015). Bu etkileşim sürecinde teknolojinin gelişmesi, yeni gelişmelere ve toplum hayatında farklı etkilere neden olmuştur. $\mathrm{Bu}$ farklı etkiler olumlu ve olumsuz sonuçlar doğurabilmektedir. Böyle riskli sonuçlar günümüzde fen eğitiminde araştırılması gereken konular olduğunu göstermektedir (Genç \& Genç, 2017). Bu konulardan bir tanesi de günümüzde gazetelerde, internette, televizyonda sık sik gündeme gelen yüksek derecede öneme sahip olan organ bağış1 konusudur.

Organ bağışı, kişinin ölmeden önce kendi hür iradesiyle, yaşamını yitirdiğinde organlarını hasta olan bir başka kişinin kullanmasına onay vermesidir (Organ Nakli Koordinatörleri Derneği [Onkod], 2017). Kişi ölmeden önce organlarını bağışlamamışsa, beyin ölümü gerçekleşmemiş ve organlar işlevini kaybetmemişken uzmanların gerekli gördüğü hallerde birinci derecede yakın akrabalarının rızası alınarak da organları bağışlanabilir. Organ nakli ise kadavradan ya da canlı kişilerden temin edilen organların, fonksiyonlarını yerine getiremeyen doku ya da organların yerine yerleştirilmesidir. Batı ülkelerinde organ nakli genellikle kadavradan yapılmaktayken, ülkemizde ağırlıklı olarak canlı vericilerden (donör) yapılmaktadır (Kavurmac1, Karabulut, \& Koç, 2014; Özmen, Çetinkaya, Sarızeybek, \& Zeybek, 2008). Ülkemizde organ bağışı ve nakli konusundaki uygulamaların hukuki dayanağı, 1979 yılında çıkarılan ve 1982'de tekrar gözden geçirilen "Organ ve Doku Alınması, Saklanmas1, Aşılanması ve Nakli” yasasıdır (Baykan vd., 2009; Efil, Şişe, Üzel, \& Eser, 2013; Özmen vd., 2008). Nakledilecek organlar canlı vericilerden ya da beyin ölümü gerçekleşmiş kişilerden alınabilmektedir (Sungur \& Mayda, 2014). Günümüzde nakli gerçekleştirilebilen organ ve dokulara akciğer, karaciğer, ince bağırsak, kalp, kalp kapağı, pankreas, böbrek, kemik iliği ve kornea örnek olarak verilebilir (Bölükbaş, Eyüpoğlu, \& Kurt, 2004).

Çetin ve Harman (2012) beyin ölümü gerçekleşmiş herkesten organ nakli yapılamayacağını, uzmanların yoğun bakım servisinde kesin tanı koyduğu, beyin ölümü gerçekleşen kimselerden organ nakli yapılabileceğini belirtmiştirlerdir. Kişiler organ bağışında bulunabilmek için 18 yaşını doldurmuş olmalı, yaşarken iki tanık ile birlikte yetkili sağlık kurum ve kuruluşlarına organlarını bağışladıklarını beyan etmeli ve organlarını bağışladığına dair formu doldurmalıdırlar (Akış vd., 2008). Devlet hastaneleri, üniversite hastaneleri, toplum sağlığ1 merkezleri, bazı aile sağlığ̀ merkezleri ile ilçe ve il sağlık müdürlükleri organ bağış formu düzenlemeye yetkili kurum ve kuruluşlardır (Uzuntarla, 2016).

Organ bağışı ve organ nakli hekimlerin çalışma alanına girmesine karşın organ bağışının yaygınlaşması için dini kurumların ve eğitim öğretim kurumlarının da işbirliği içinde çalışması gerekir (Akçöltekin, 2014) ve yurttaşlarımız da bu konuda olumlu tutum içinde olmalıdır (Koçak, Aktaş, Şenol, Kaya, \& Bilgin, 2010). Özer Gök vd., (2008) insanların organ nakliyle ilgili görüşlerinde eğitim düzeylerinin, sosyoekonomik durumlarının ve mensubu olduğu dinin etkili olduğunu belirtmiştir. Ülkemizdeki alan yazın incelendiğinde bu konuda yapılan çalışmaların çoğunlukla üniversite öğrencilerinin (Bedi vd., 2015; Demir Doğan, Uzun, Kaya, Ekinci, \& Altınkaynak, 2016; Güler, Yava, Karakaş Doğan, \& Perim Ketenciler, 2017; Harman \& Çökelez, 2017; Kavurmac1, Karabulut, \& Koç, 2014; Özer Gök vd., 2008; Özpulat, 2017; Sungur 
\& Mayda, 2014; Vicdan, Peker, \& Üçer, 2011; Yaşar vd., 2008), lise öğrencilerinin (Çetin \& Harman, 2012; Tarhan, Dalar, Yıldırımoğlu, Sayar, \& Altın, 2012; Uzuntarla, 2016), hemşirelerin (Aytaş, Kartalcı, \& Ünal, 2011), sınıf öğretmenlerinin (Akçöltekin, 2014) ve üniversite personelinin (Akış vd., 2008 ) görüşlerini ve bilgi düzeylerini belirlemeye yönelik olduğu, ancak ortaokul düzeyinde yapılan çalışmaların (Öz, Ayranc1, Arslantaş, \& Ünsal, 2016; Tetik \& Cebesoy, 2018) ise çok az olduğu görülmektedir. Yapılan bu çalışmalarda örneğin;

Tetik \& Cebesoy’un (2018) 272 ortaokul öğrencisinin organ bağışı ve nakline yönelik görüşlerini belirlemek amacıyla yaptığı çalışmada öğrencilerin, \%60'ının organ bağışı konusunda bilgilerinin olmadığı, \%71'inin organ bağışlamak için hangi şartların gerekli olduğunu bilmedikleri tespit edilmiştir. Bunun yanında öğrencilerin büyük kısmının böbrek, karaciğer ve kalbin naklinin gerşekleştirildiğini bildikleri belirtilmiştir. Siebelink, Geerts, Albers, Roodbol ve van de Wiel'in (2011) yaptığı çalışmada 12-15 yaşları arasındaki çocukların, organ bağışı konusunu düşünebilecek kapasiteye sahip oldukları belirtilmiştir. Siebelink, Verhagen, Roodbol, Albers, \& Van de Wiel'in (2017) çalışmasında ise öğrencilerin organ bağışı konusunda bilgilendirilmesi için en uygun yaş diliminin 10-11 yaşları arası olduğu rapor edilmiştir. Tarhan vd.'nin (2012), organ bağışı konusunda lise öğrencileri ile yaptığı çalışmada öğrencilerin,\%58'inin organ bağışı konusunda yeterli bilgiye sahip oldukları ve \%81'inin organ bağışı ve naklinin yapılmasını onayladıkları tespit edilmiştir. Çetin ve Harman'ın (2012) lise öğrencileri ile yaptığı çalışmada öğrencilerin \%30'unun organ bağışı konusunda bilgilerinin olduğu, bunun yanında öğrencilerin \%43'ünün dinen organları bağışlamanın bir sakıncası olmadığını belirttikleri rapor edilmiştir. Üniversite öğrencileri ile yapılan çalışmalarda örneğin;

Yaşar vd.'nin (2008) çalışmasında öğrencilerin organ bağışı ve nakli konusunda yetersiz bilgiye sahip oldukları, buna karşın Aytaş vd.'nin (2011) bir grup hemşirenin organ bă̆ışına bakış açılarını inceledikleri çalışmada, katılımcıların yeterli bilgilerinin olduğu belirtilmiştir. Bedi vd.'nin (2015) tıp fakültesi öğrencileri ile yaptıkları çalışmada, öğrencilerin organ bağışına yönelik tutumlarının olumlu olduğu; ancak öğrencilerin bu konudaki bilgilerinin sınırlı olduğı tespit edilmiştir. Demir Doğan vd.'nin (2016) sağlıkla ilgili bölümlerde öğrenim görmekte olan öğrencilerin \%39'unun organ bağışında bulunmak istedikleri, \% 57'sinin konu hakkında bilgisinin iyi olduğu sonucuna ulaşılmıştır. Özpulat'ın (2017) öğrencilerin kan ve organ bağışına ilişkin düşüncelerini belirlemek amacıyla yaptığı çalışmasında ise, öğrencilerin \%41'inin organlarını bağışlamak istedikleri buna karşın \%65'inin kan bağışı yapmak istedikleri tespit edilmiştir.

Organ bağışı ve organ nakli konusu, 2013 yılı Milli Eğitim Bakanlığı (MEB) ortaokul 7.sınıf fen bilimleri öğretim programında yer almaktayken (MEB, 2013), 2018 yılında yapılan güncellemelerle birlikte 6. Sınıf Fen Bilimleri Öğretim Programı kazanımları içerisine dahil edilmiştir (MEB, 2018). Program doğrultusunda öğrencilerin konu ile ilgili bilgiler edinmesi ve öğrencilere konunun toplumsal dayanışma açısından önemli olduğu kazandırılmak istenmektedir. Çünkü, erken yaşlarda organ bağışı ve nakli konusu gündeme getirilmelidir (Siebelink, Geerts, Albers, Roodbol, \& van de Wiel, 2011). Eğer organ bağışı ve nakli konusu erken yaşlarda gündeme gelmezse, anne ve babalar çocuklarının herhangi bir nedenden dolayı beyin ölümleri gerçekleştiklerinde sağlıklı bir karar verip, çocuklarının organlarını bağışlamada zorluk çekebilmekte, 
dolayısıyla ebeveynler, çocuklarının böyle bir durumda nasıl karar vereceklerini bilmeleri durumunda kendileri organ bağışı konusunda daha kolay karar verebilmektedir (Siebelink vd diğerleri, 2011). Eğitim kurumlarında organ bağışı ve nakli konusuna yer verildiğinde, öğrenciler bu konulara yönelik olumlu tutum ve bilgi kazanmaktadır (Kavurmacı vd., 2014; Liu, Peng, Zhang, Qiao, \& Hao, 2015; Yaşar vd., 2008). Organ bağışı konusundaki edinilen bilgiler sayesinde bireylerin bağış yapma oranları daha yüksek olmaktadır (Balc1 \& Şahingöz, 2014). Çünkü organ bağış1 konusunda karşılaşılan en büyük problem, organ bağışının az olmasıdır (Burra vd., 2005). Böylece bu konuların fen bilimleri öğretim programında yer alarak öğrencilerin bu konulara yönelik bilgi ve görüşlerinin belirlenmesi önem arz etmektedir. Buradan yola çıkılarak bu çalışmada, ortaokul 7. ve 8. sınıf öğrencilerinin organ bağışı ve organ nakli hakkındaki bilgilerinin ve tutumlarının incelenmesi amaçlanmıştır. $\mathrm{Bu}$ amaçla ortaokul düzeyinde öğrencilerin organ bağışına yönelik bilgi düzeyleri ve görüşleri araştırılmış olup aşağıdaki araştırma sorusuna cevap aranmıştır:

7. ve 8. sınıf öğrencilerinin organ bağışı ve organ nakli konusundaki bilgileri ve görüşleri nelerdir?

\section{Yöntem}

Çalışmanın yöntemi, bir konu hakkında katılımcıların görüşlerinin ya da ilgi, beceri ve yetenek gibi özelliklerinin belirlendiği nicel araştırma yöntemlerinden kesitsel tarama araştırmasıdır (Fraenkel \& Wallen, 2006).

\section{Evren ve Örneklem}

Çalışmanın evreni 2017-2018 eğitim-öğretim yılı birinci yarıyılda Aydın ili Kuyucak ilçesindeki devlet okullarında öğrenim görmekte olan 7.sınıf ve 8. sınıf öğrencileridir. Ilçede toplamda 10 okul 5617 . ve 8 . Sınıf öğrencisi bulunmaktadır. Araştırma kapsamında ilçedeki tüm okullara ulaşılmış ve tüm gruplardan veri toplanmıştır. Hedeflenen öğrenci grubundan yalnızca 48 öğrenciye (devamsızlık, hastalık, araştırmaya katılmak istememe vb. sebeplerden) ulaşılamamıştır. Çalışmada yol ve zaman açısından tasarruflu olması göz önüne alınarak uygun örnekleme yöntemi kullanılmıştır. Veriler 2017-2018 eğitim-öğretim yılı birinci yarıyılda Aydın İli Kuyucak ilçesi devlet okullarında 7. ve 8. sınıf düzeyinde öğrenim gören 513 (264 kız, 249 erkek) öğrenciden toplanmıştır.

"Organ bağışı ve organ nakli” konusu 7. sınıf fen bilimleri ders programında yer almaktadır. Bu çalışmada bu konuyu öğrenen öğrencilerin bilgi ve görüşlerinin araştırılması amaçlandığı için Aydın ili Kuyucak ilçesindeki ortaokullarda sadece 7. ve 8. sınıf düzeyinde öğrenim görmekte olan öğrenciler çalışmanın örneklemini oluşturmaktadır. Örneklemi oluşturan okullar ve öğrenci sayıları Tablo 1'de belirtilmiştir. Etik nedenlerden dolayı okul isimleri açıkça verilmemiş $\mathrm{O} 1, \mathrm{O} 2, \mathrm{O} 3, \ldots$ şeklinde numaralandırılmıştır. 
Tablo 1

Evreni ve Örneklemi Oluşturan Okullar ve Öğrenci Sayıları

\begin{tabular}{|c|c|c|c|c|c|c|c|c|}
\hline \multirow[b]{2}{*}{ Okul } & \multicolumn{5}{|c|}{ Örneklem } & \multicolumn{3}{|c|}{ Evren } \\
\hline & Cinsiyet & 7. Sinıf & 8. Sinif & Toplam & $\begin{array}{l}\text { Genel } \\
\text { Toplam }\end{array}$ & 7. Sinif & 8. Sinıf & Toplam \\
\hline \multirow[t]{2}{*}{$\mathrm{O} 1$} & Kız & 58 & 54 & 112 & \multirow{2}{*}{207} & \multirow{2}{*}{124} & \multirow{2}{*}{106} & \multirow{2}{*}{230} \\
\hline & Erkek & 49 & 46 & 95 & & & & \\
\hline \multirow[t]{2}{*}{$\mathrm{O} 2$} & $\mathrm{~K} 1 \mathrm{z}$ & 5 & 11 & 16 & \multirow{2}{*}{26} & \multirow{2}{*}{14} & \multirow{2}{*}{13} & \multirow{2}{*}{27} \\
\hline & Erkek & 7 & 3 & 10 & & & & \\
\hline \multirow[t]{2}{*}{$\mathrm{O} 3$} & Kız & 10 & 6 & 16 & \multirow{2}{*}{39} & \multirow{2}{*}{22} & \multirow{2}{*}{17} & \multirow{2}{*}{39} \\
\hline & Erkek & 9 & 14 & 23 & & & & \\
\hline \multirow[t]{2}{*}{$\mathrm{O} 4$} & Kız & 4 & 3 & 7 & \multirow{2}{*}{22} & \multirow{2}{*}{15} & \multirow{2}{*}{16} & \multirow{2}{*}{31} \\
\hline & Erkek & 8 & 7 & 15 & & & & \\
\hline \multirow[t]{2}{*}{$\mathrm{O} 5$} & $\mathrm{~K} 1 \mathrm{z}$ & 14 & 5 & 19 & \multirow{2}{*}{36} & \multirow{2}{*}{23} & \multirow{2}{*}{22} & \multirow{2}{*}{45} \\
\hline & Erkek & 7 & 10 & 17 & & & & \\
\hline \multirow[t]{2}{*}{ O6 } & $\mathrm{K} 1 \mathrm{z}$ & 1 & 8 & 9 & \multirow{2}{*}{20} & \multirow{2}{*}{7} & \multirow{2}{*}{13} & \multirow{2}{*}{20} \\
\hline & Erkek & 6 & 5 & 11 & & & & \\
\hline $\mathrm{O} 7$ & $\mathrm{~K} 1 \mathrm{z}$ & 12 & 5 & 17 & 25 & 24 & 12 & 36 \\
\hline & Erkek & 12 & 6 & 18 & (3) & $2 r$ & 12 & \\
\hline $\mathrm{O} 8$ & Kız & 13 & 23 & 36 & 60 & 24 & 36 & 70 \\
\hline & Erkek & 20 & 13 & 33 & 8 & דונ & 8 & 80 \\
\hline O9 & Kız & 4 & 6 & 10 & 10 & 5 & 12 & 10 \\
\hline & Erkek & 2 & 6 & 8 & 10 & J & 10 & 10 \\
\hline $\mathrm{O} 10$ & $\mathrm{~K} 1 \mathrm{z}$ & 10 & 12 & 22 & & & & \\
\hline & Erkek & 13 & 6 & 19 & 41 & 24 & 21 & $4 J$ \\
\hline & Toplam & 264 & 249 & 513 & 513 & 292 & 269 & 561 \\
\hline
\end{tabular}

\section{Veri Toplama Aracı}

Çalışmada kişisel bilgiler ile ilgili 7 sorudan ve organ bağışı ve nakli hakkındaki bilgi ve görüşler ile ilgili 12 sorudan oluşan anket kullanılmıştır. Akış vd., (2008) tarafından Tıp Fakültesi Sağlık Personeline yönelik geliştirilen 13 sorudan oluşan Organ Bağışı Bilgi Düzeyi Anketi, ortaokul öğrencilerine uygulanacağı için uzman görüşüne sunulmuştur. Uzman görüşü için, sosyobilimsel konular alanında doktorasını tamamlamış üç akademisyenden içerik ile ilgili görüş alınmıştır. Dilbilgisi kontrolü için bir Türkçe Öğretmeni, ve soruların fen bilgisi programı içeriğine uygunluğu için iki Fen Bilimleri Öğretmenin görüşleri alınarak uzmanların \%70-80 oranında anket sorularında uyuşma gösterdikleri görüşler eleştiriler doğrultusunda düzeltmeler yapılarak ankette kullanılmıştır (Büyüköztürk, Çakmak, Akgün, Karadeniz, \& Demirel, 2016). Anket soruları içerisinde yer alan bir soru (sizce hangi birim ya da birimlere organ bağışında bulunulabilir?) uzman görüşlerinde belirtilen öneriler doğrultusunda 
(yanıtları arasındaki dispanser seçeneği öğrenciler tarafından pek kullanılmayan bir kelime olması) ve bilemeyecekleri düşünüldüğünden seçeneklerden çıkartılmıştır. Ayrıca soruları yanıtlarken öğrencilerin birden fazla seçeneği işaretleyebilmeleri için anketin yönerge kısmına yanıtı evet hayır olan sorular dışında birden fazla seçeneği işaretleyebilirsiniz şeklinde ifade eklenmesi uzman görüşleri dikkate alınarak yapılmıştır. Son hali verilen anket bir tanesi açık, 11'i kapalı uçlu olmak üzere 12 sorudan oluşmaktadır.

Anket uygulaması sınıf ortamında ve birinci yazar rehberliğinde gerçekleştirilmiş toplamda 25 dakika sürmüştür. Veri toplayıcı araştırmacı tüm sınıflarda standart açıklamalar yapmıştır. Çalışmaya katılımın gönüllülük arz ettiği, diledikleri zaman çalışmadan çekilebileceklerini açıklamıştır. Bu açıklamaların ardından bazı öğrenciler çalışmaya katılmak istemediklerini belirtmiştir. Bunun haricinde araştırmacı ile katılımcılar arasında herhangi bir etkileşim olmamıştır.

\section{Veri Analiz Yöntemi}

Anket verileri analiz edilirken, kodlamalar yapılmıştır ve verilerin frekans ve yüzde değerleri verilerek betimsel analiz kullanılmıştır. Birinci soru haricindeki sorular evet hayır, ya da tartışmaya açık olmayan cevaplar içerdiği için (bilgi kaynağı vb.) frekans ve yüzde değerleri hesaplanmıştır. Birinci sorunun analizi yapılırken her iki örneklemden rastgele seçilen 50 öğrencinin cevabı ayrı ayrı kodlanmış olup daha sonra üç araştırmacı bir araya gelerek fikir ayrılığı olan kısımları tartışmışlardır. Kodlayıcı güvenirliği hesaplanırken Miles ve Huberman'ın (1994) önerdiği Güvenirlik = Görüş Birliği / (Görüş Birliği + Görüş Ayrılığı) formülü kullanılarak görüş birliği $(n=45)$ ve görüş ayrılığı $(n=5)$ bulunmuştur ve kodlayıcı güvenirliği \%90 olarak hesaplanmıştır.

Kodlayıcılar arasında uzlaşma sağlandıktan sonra kalan veriler araştırmacılar arasında eşit paylaşılarak bağımsız analiz edilmiştir. Öğrenciler organ bağışı ve organ nakli nedir sorusunda organ bağışını ayrı, organ naklini ayrı şekilde tanımlanmışsa yeterli, tanımlardan sadece birini yapmışsa yetersiz, tek bir tanımın içinde hem organ bağışı hem de organ nakli ile ilgili bilgi ve görüşler vermişse karmaşık, soruyu yanıtsız bırakmışsa cevap yok şeklinde kodlama yapılmıştır. 


\section{Bulgular}

Öğrencilerin kişisel bilgilerini tanımlayan sosyodemografik özellikleri Tablo 2'de verilmiştir.

\section{Tablo 2}

Öğrencilerin Sosyodemografik Özellikleri

\begin{tabular}{|c|c|c|c|c|c|}
\hline \multicolumn{2}{|c|}{ Özellikler } & \multicolumn{2}{|c|}{ 7. Sinıf } & \multicolumn{2}{|c|}{ 8. Sinıf } \\
\hline & & $f$ & $\%$ & $f$ & $\%$ \\
\hline \multirow{4}{*}{$\stackrel{\mathbb{\lambda}}{\pi}$} & 12 & 143 & 54.17 & 1 & 0.40 \\
\hline & 13 & 114 & 43.18 & 154 & 61.85 \\
\hline & 14 & 6 & 2.27 & 93 & 37.35 \\
\hline & 15 & 1 & 0.38 & 1 & 0.40 \\
\hline \multirow{2}{*}{ 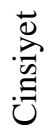 } & Erkek & 133 & 50.38 & 116 & 46.59 \\
\hline & $\mathrm{K}_{1 \mathrm{z}}$ & 131 & 49.62 & 133 & 53.41 \\
\hline \multirow{6}{*}{ 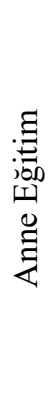 } & İlkokul & 139 & 52.65 & 132 & 53.01 \\
\hline & Ortaokul & 67 & 25.38 & 68 & 27.31 \\
\hline & Lise & 37 & 14.02 & 29 & 11.65 \\
\hline & Üniversite & 12 & 4.55 & 11 & 4.42 \\
\hline & Okur-yazar değil & 5 & 1.89 & 7 & 2.81 \\
\hline & Bilmiyor & 4 & 1.52 & 2 & 0.80 \\
\hline \multirow{6}{*}{ 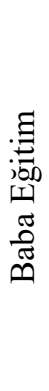 } & İlkokul & 109 & 41.29 & 108 & 43.37 \\
\hline & Ortaokul & 81 & 30.68 & 72 & 28.92 \\
\hline & Lise & 40 & 15.15 & 47 & 18.88 \\
\hline & Üniversite & 28 & 10.61 & 18 & 7.23 \\
\hline & Okur-yazar değil & 2 & 0.76 & 1 & 0.40 \\
\hline & Bilmiyor & 4 & 1.52 & 3 & 1.20 \\
\hline \multirow{3}{*}{ 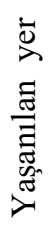 } & Köy & 124 & 46.97 & 123 & 49.40 \\
\hline & İlçe & 80 & 30.30 & 71 & 28.51 \\
\hline & Kasaba & 60 & 22.73 & 55 & 22.09 \\
\hline \multirow{7}{*}{ 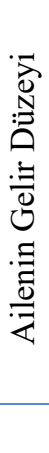 } & $1000-1500 \mathrm{TL}$ & 104 & 39.39 & 105 & 42.17 \\
\hline & $1501-2000 \mathrm{TL}$ & 53 & 20.08 & 31 & 12.45 \\
\hline & $2001-2500 \mathrm{TL}$ & 29 & 10.98 & 26 & 10.44 \\
\hline & $2501-3000 \mathrm{TL}$ & 35 & 13.26 & 35 & 14.06 \\
\hline & 3000 TL ve üzeri & 29 & 10.98 & 40 & 16.06 \\
\hline & Bilmiyor & 14 & 5.30 & 12 & 4.82 \\
\hline & Toplam & 264 & 100.00 & 249 & 100.00 \\
\hline
\end{tabular}


Tablo 2'den elde edilen bulgulara göre 7. sınıf ve 8. sınıf öğrencilerinin yaş aralığı 12-15 arasında olduğu, yaş ortalamalarının ise 7. sınıflarda 12.5, 8. sınıflarda 13 olduğu görülmektedir. Araştırmaya katılan 7. sınıf öğrencilerinin \%50.38'i erkek, \%49.62'si kız, 8. sinıf öğrencilerinin \%46.59'u erkek, \%53,41'i kız öğrencilerden oluşmaktadır. Öğrencilerin anne eğitim durumları incelendiğinde her iki grupta da ilkokul mezunu annelerin sayısının diğerlerine göre fazla olduğu, ortaokul lise üniversite ve okuryazar olmayan anne sayısının da her iki grupta benzer oranlarda olduğu görülmektedir. Ayrıca 7. sınıflardan dört, 8. sınıflardan da iki öğrenci annesinin eğitim düzeyini bilmediklerini belirtmişlerdir.

Baba eğitim durumları incelendiğinde her iki grupta da ilkokul mezunu babaların sayısının diğerlerine göre fazla olduğu, ortaokul-lise-üniversite ve okuryazar olmayan baba sayısının da her iki grupta benzer oranlarda olduğu görülmektedir. Öte yandan, 7. sınıflardan dört, 8. sınıflardan da üç öğrenci babasının eğitim düzeyini bilmediklerini belirttikleri görülmektedir. Tablo 2 dikkatle incelendiğinde anne ve babaların çoğunluğunun ilkokul mezunu olduğu görülmekte ancak babaların eğitim durumlarının anne eğitim durumlarına göre daha iyi olduğu görülmektedir. Öğrencilerin ve ailelerinin yaşadıkları yerler incelendiğinde her iki gruptaki öğrencilerin büyük çoğunluğunun köyde yaşadığ 1 diğer öğrencilerin de ağırlıklı olarak ilçe ve kasabada yaşadıkları görülmektedir.

Ailelerin gelir düzeyine bakıldığında her iki gruptaki öğrencilerin de gelir düzeylerinin benzer aralıklarda olduğu, ailelerin çoğunluğunun 1000-1500 TL gelire sahip oldukları, üst limit olarak belirlenen 3000 TL üzerinde gelire sahip az sayıda öğrenci olduğu görülmektedir. Ayrıca 7. sinıflardan 14, 8. sınıflardan 12 öğrencinin ailesinin gelir miktarını bilmediği görülmektedir.

Öğrencilere uygulanan organ bağışı ve nakli bilgi düzeyleri ve görüşleri anketi verilerine göre; birinci soruda öğrencilere organ nakli ve organ bağışının tanımları sorulmuştur. Öğrencilerin verdikleri yanıtlar Tablo 3 'te belirtilmiştir.

Tablo 3

Öğrencilerin Organ Bă̆ışı ve Organ Nakli Tanımları

\begin{tabular}{lcccc}
\hline & \multicolumn{2}{c}{ 7. Sınıf Öğrencileri } & \multicolumn{2}{c}{ 8. Sinıf Öğrencileri } \\
\hline Yetersiz & $f$ & $\%$ & $f$ & $\%$ \\
Yeterli & 175 & 66.29 & 201 & 80.72 \\
Karmaşık & 45 & 17.05 & 14 & 5.62 \\
Cevap yok & 19 & 7.20 & 9 & 3.61 \\
& 25 & 9.47 & 25 & 10.04
\end{tabular}

Tablo 3'e göre her iki gruptaki öğrencilerin çoğunluğunun organ nakli ve organ bağışı tanımlamalarının yetersiz olduğu görülmekte iken, soruyu cevapsız bırakan öğrenci sayıları her iki grupta da eşittir. Öte yandan 7. sınıf öğrencilerinin organ bağışı ve organ nakli tanımlamalarının 8. sınıf öğrencilerine göre daha yeterli düzeyde olduğu görülmektedir. Öğrencilerin organ bağışı ve organ nakline ilişkin tanımlarından örnekler aşağıda sunulmuştur: 
'Organ bağışı, organımızı isteyerek bir başkasına vermek' (Yetersiz kategorisi)

'Organ nakli, sağlam organları başka kişilere takmak' (Yetersiz kategorisi)

'Organ bağışı, insanın öldükten sonar da organı bağışlanabilir, beyin ölümü gerçekleşmişse ya da ölmeden de hastanelere giderek organını bağışlayabilir' (Yeterli kategorisi)

'Organ nakli, sağlam bir organın hasta bir hastaya nakledilmesidir' (Yeterli kategori)

'Organ bağışı, beyin ölümü gerçekleştikten sonra sağlam organların nakledilmesi' (Karmaşık kategorisi)

'Organ nakli, ihtiyaç duyulduğunda bağışlanan organ' (Karmaşık kategorisi)

Sorunun doğru cevabı şu şekildedir: Organ bağışı, kişinin ölmeden önce kendi hür iradesiyle, yaşamını yitirdiğinde organlarını hasta olan bir başka kişinin kullanmasına onay vermesidir (Organ Nakli Koordinatörleri Derneği [Onkod], 2017). Organ nakli, beyin ölümü gerçekleşmiş kişilerden ya da sağlam kişilerden alınan organların, yetersizlik yaşanan organlarla değiştirilmesidir (Özmen vd., 2008).

Ikinci soruda öğrencilere organ bağışı hakkındaki bilgilerini nerelerden edindikleri sorulmuştur. Verilen yanıtlar Tablo 4'te belirtilmiştir.

Tablo 4

Öğrencilerinin Organ Bă̆ışı Hakkındaki Bilgileri Edinme Yerleri

\begin{tabular}{lcccc}
\hline & \multicolumn{2}{c}{ 7. Sinıf Öğrencileri } & \multicolumn{2}{c}{ 8. Sınıf Öğrencileri } \\
\hline & $f$ & $\%$ & $f$ & $\%$ \\
\hline Öğretmen & 163 & 61.74 & 128 & 51.41 \\
İnternet & 114 & 43.18 & 130 & 52.21 \\
TV & 96 & 36.36 & 56 & 22.49 \\
Çevre & 82 & 31.06 & 97 & 38.96 \\
Organ Bağış Merkezi & 57 & 21.59 & 54 & 21.69 \\
Özel Doktor & 42 & 15.91 & 30 & 12.05 \\
\hline
\end{tabular}

Tablo 4'e göre öğrencilerinin yanıtları incelendiğinde organ bağışı bilgi edinme yeri olarak en sık tekrarlanan yanıtların 7. sınıf öğrencilerinde öğretmen $(n=163)$ sonra sırasıyla internet $(n=114)$, TV $(n=96)$, çevre $(n=82)$, organ bağışı merkezi $(n=57)$ ve özel doktor $(\mathrm{n}=42)$ olduğu görülmekteyken, 8. sinıf öğrencilerinde en sık tekrarlanan yanıtların internet $(n=130)$ sonra sirasıyla öğretmen $(n=128)$, çevre $(n=97), T V(n=56)$, organ bağışı merkezleri $(n=54)$ ve özel doktor $(n=30)$ olduğu görülmektedir. Genel olarak 7. sınıf öğrencilerinin büyük kısmı organ bağışı ve organ nakli konusundaki bilgilerini öğretmenlerden (\%61.74) edinirken 8. sinıf öğrencilerinin internetten (\%52.21) ve öğretmenlerden (\%51.41) edindikleri görülmektedir.

Üçüncü soruda öğrencilere hangi birim ya da birimlere organ bağışında bulunulabilir diye sorulmuştur. Verilen yanıtlar Tablo 5 'te belirtilmiştir. 
Tablo 5

Organ Bă̆ışıında Bulunulabilen Birimler

\begin{tabular}{lcccc}
\hline & \multicolumn{2}{c}{ 7. Sinıf Öğrencileri } & \multicolumn{2}{c}{ 8. Sinıf Öğrencileri } \\
\hline & $f$ & $\%$ & $f$ & $\%$ \\
\hline Devlet Hastaneleri & 154 & 58.33 & 149 & 59.84 \\
Üniversite Hastaneleri & 131 & 49.62 & 141 & 56.63 \\
Özel Poliklinikler & 126 & 47.73 & 95 & 38.15 \\
İl Sağlık Müdürlüğü & 87 & 32.95 & 79 & 31.73 \\
Aile Hekimliği & 53 & 20.08 & 35 & 14.06 \\
Merkezi & & & &
\end{tabular}

Tablo $5^{`} \mathrm{e}$ göre öğrencilerinin yanıtları incelendiğinde organ bağışında bulunulabilecek birimler olarak en sık tekrarlanan yanıtın 7. sınıf ögrencilerinde devlet hastaneleri $(n=154)$ sonra sirasiyla üniversite hastaneleri $(n=131)$, özel poliklinikler $(n=126)$, il sağlık müdürlükleri $(n=87)$ ve aile hekimliği merkezi $(n=53)$ olarak görülmekteyken, 8. sınıf öğrencilerinde en sık tekrarlanan yanıtın devlet hastaneleri $(n=149)$, sonra sirasıyla üniversite hastaneleri $(n=141)$, özel poliklinikler $(n=95)$, il sağlık müdürlükleri $(n=79)$ ve aile hekimliği merkezi $(n=35)$ olarak görülmektedir. Genel olarak 7. sınıf öğrencilerinin büyük kısmı devlet hastanelerini (\% 58,33), 8. sınıf öğrencilerinin çoğunluğu devlet hastaneleri $(\% 59,84)$ ve üniversite hastanelerini (\% 56,63 ) organ bağışında bulunulan birimler olarak belirtmektedirler. Devlet hastaneleri, üniversite hastaneleri, toplum sağlığı merkezleri, bazı aile sağlığı merkezleri ile ilçe ve il sağlı müdürlükleri organ bağış formu düzenlemeye yetkili kurum ve kuruluşlar olarak bilinmektedir (Uzuntarla, 2016).

Dördüncü soruda öğrencilere organ bağışında bulunabilmek için neler gereklidir diye sorulmuştur. Verilen yanıtlar Tablo 6'da belirtilmiştir.

Tablo 6

Organ Bağışıında Bulunulabilme Şartları

\begin{tabular}{lcccc}
\hline & \multicolumn{2}{c}{ 7. Sinıf Öğrencileri } & \multicolumn{2}{c}{ 8. Sınıf Öğrencileri } \\
\hline & $f$ & $\%$ & $f$ & $\%$ \\
\hline Sağlık Raporu & 215 & 81.44 & 218 & 87.55 \\
Nüfus Bilgilerini İçeren & 170 & 64.39 & 161 & 64.66 \\
Kimlik & & & & \\
1.Derece Akraba & 115 & 43.56 & 74 & 29.72 \\
Sadece Doktor Bilgisi & 20 & 7.58 & 33 & 13.25 \\
Diğer & 16 & 6.06 & 9 & 3.61 \\
\hline
\end{tabular}

Tablo 6'ya göre öğrencilerin yanıtları incelendiğinde organ bağışında bulunabilme şartları olarak en sık tekrarlanan yanıtın 7. sınıf öğrencilerinde sağlık raporu $(n=215)$ sonra sırasıyla nüfus bilgilerini içeren kimlik $(n=170)$, birinci dereceden akraba $(n=115)$, sadece doktor bilgisi $(n=20)$ ve diğer $(n=16)$ [doku uyumu 5 öğrenci, yaş sınırı 4 öğrenci, aile izni 2 öğrenci, yeşil kart, anket kullanmak, beyin ölümü, 
organın çift olması ve organ bağış kartı 1'er öğrenci] olarak görülmekteyken 8. sınıf öğrencilerinde en sık tekrarlanan yanıtın sağlı raporu $(n=218)$ sonra sırasıyla nüfus bilgilerini içeren kimlik $(n=161)$, birinci dereceden akraba $(n=74)$, sadece doktor bilgisi $(n=33)$ ve diğer $(n=9)$ [onsekiz yaş 4 öğrenci, organ bağış kartı 2 öğrenci, doku uyumu, diyanet işi ve aile izni 1' er öğrenci) olarak belirtmişlerdir. Genel olarak 7. ve 8. sınıf öğrencilerinin çoğunluğu nüfus bilgilerini içeren kimlik ve sağlık raporunun organ bağışında bulunmak için gerekli olduğunu belirtmiştir. Ülkemizde bireylerin organ bağışında bulunabilmeleri için 18 yaşını doldurmuş olmaları, yaşarken iki tanık ile birlikte yetkili sağlık kurum ve kuruluşlarına organlarını bağışladıklarını beyan etmeleri ve organlarını bağışladığına dair formu doldurmaları gerekmektedir (Akış vd., 2008). Sağlık raporu organ bağışlamak için gerekli değildir.

Beşinci soruda öğrencilere organ bağışı için doku uyumu gerekli midir diye sorulmuştur. Verilen yanıtlar Tablo 7'de belirtilmiştir.

Tablo 7

Doku Uуити Gerekliliği

\begin{tabular}{lcccc}
\hline & \multicolumn{2}{c}{ 7. Sınıf Öğrencileri } & \multicolumn{2}{c}{ 8. Sinıf Öğrencileri } \\
\hline Evet & $f$ & $\%$ & $f$ & $\%$ \\
Hayır & 249 & 94.32 & 233 & 93.57 \\
\hline
\end{tabular}

Tablo 7'ye göre 7. sınıf öğrencilerinden organ bağışı için 249 öğrenci doku uyumunun gerekli olduğunu, 15 öğrenci gerekli olmadığını belirtmektedir. 8. sınıf ögrencilerinden 233'ü doku uyumunun gerekli olduğunu, 14'ü gerekli olmadığını belirtmiştir. 8. sınıf öğrencilerinden 2 öğrenci ise soruyu yanıtsız bırakmıştır. Genel olarak 7. ve 8. sınıf öğrencilerinin büyük çoğunluğunun organ bağışı için, sorunun doğru cevabı olan doku uyumunun gerekli olduğunu belirttiği görülmektedir.

Altıncı soruda öğrencilere daha önceden organ bağışında bulunmamış bir kişiden hangi şartlarda organ nakli gerçekleştirilebilir diye sorulmuştur. Verilen yanıtlar Tablo 8'de belirtilmiştir.

Tablo 8

Organ Naklinde Bulunmak İçin Gerekli Şartlar

\begin{tabular}{lcccc}
\hline & \multicolumn{2}{c}{ 7. Sınıf Öğrencileri } & \multicolumn{2}{c}{ 8. Sını Ö̆̆gencileri } \\
\hline & $f$ & $\%$ & $f$ & $\%$ \\
\hline Beyin Ölümü & 164 & 62.12 & 146 & 58.63 \\
Birinci Derce İki & 150 & 56.82 & 111 & 44.58 \\
Yakını Onayı & 124 & 46.97 & 144 & 57.83 \\
Doktor Onayı & 34 & 12.88 & 39 & 15.66 \\
Suni Solunum & 15 & 5.68 & 24 & 9.64 \\
Cihazına Bağlı Olma & & & \\
Yoğun Bakımda & & &
\end{tabular}


Tablo 8'e göre öğrencilerin yanıtları incelendiğinde organ bağışında bulunmak için gerekli şartlar arasında her iki grupta da en sık tekrarlanan yanıtın beyin ölümünün gerçekleşmiş olması en az tekrarlanan yanıtın ise suni solunum cihazına bağlı olma ve yoğun bakımda yatma olduğu görülmektedir. Genel olarak organ bağışında bulunmak için gerekli şartları 7. sınıf öğrencilerinin çoğunluğu beyin ölümü $(\% 62.12)$ ve birinci derece iki yakınının onayı (\%56.82) olarak belirtirken 8.sınıf öğrencilerinin çoğunluğu beyin ölümü $(\% 58.63)$ ve doktor onayı $(\% 57.83)$ olarak belirtmektedir. Sorunun doğru cevabı ise şu şekildedir: Organ nakli, beyin ölümü gerçekleşen ve hastane şartlarında ölen bireylerin organları, ilgili uzmanların beyin ölümü tanısını koyduktan sonra aile izninin olmasıyla yapılmaktadır (Kara, Salman, \& Öngel, 2012).

Yedinci soruda öğrencilere hangi organların bağışlanabileceği sorulmuştur. Verilen yanıtlar Tablo 9' da belirtilmiştir.

Tablo 9

Bağışlanabilen Organlar

\begin{tabular}{lcccc}
\hline & \multicolumn{2}{c}{ 7. Sinıf Öğrencileri } & \multicolumn{2}{c}{ 8. Sınıf Ö̆̆rencileri } \\
\hline Böbrek & $f$ & $\%$ & $f$ & $\%$ \\
Karaciğer & 249 & 94.32 & 225 & 90.36 \\
Akciğer & 232 & 87.88 & 211 & 84.74 \\
Kalp Kapă̆ı & 226 & 85.61 & 206 & 82.73 \\
Kalp & 215 & 81.44 & 179 & 71.89 \\
Pankreas & 197 & 74.62 & 189 & 75.90 \\
Kornea & 197 & 74.62 & 133 & 53.41 \\
İnce bağırsak & 188 & 71.21 & 139 & 55.82 \\
Tamamı & 187 & 70.83 & 112 & 44.98 \\
\hline
\end{tabular}

Tablo 9 incelendiğinde her iki gruptaki öğrencilerin de bağışlanabilen organlar olarak sırasıyla böbrek, karaciğer, akciğer, kalp kapağı, kalp, pankreas, kornea, ince bağırsak ve organların tamamı [böbrek, akciğer, karaciğer, kalp, kalp kapağı, kornea, ince bağırsak ve pankreas]nı belirttikleri görülmektedir. Genel olarak 7. ve 8. sınıf öğrencileri bağışlanabilen organ olarak en fazla böbrek, karaciğer ve akciğeri belirtmektedirler ve 7. sınıf öğrencilerinin çoğunluğu sorunun doğru cevabı olan belirtilen organların tamamının (\%60.98) bağışlanabileceğini belirtirken 8 . sınıf öğrencilerinin az bir kısmı organların tamamının (\%36.55) bağışlanabileceğini belirtmektedirler. 
Sekizinci soruda öğrencilere akrabalarından ya da yakın çevresinden organ bağışında bulunanlar oldu mu diye sorulmuştur. Verilen yanıtlar Tablo 10' da belirtilmiştir.

Tablo 10

Akrabası ya da Yakın Çevresinden Organ Bă̆ışında Bulunanlar

\begin{tabular}{lcccc}
\hline & \multicolumn{2}{c}{ 7. Sınıf Öğrencileri } & \multicolumn{2}{c}{ 8. Sinıf Öğrencileri } \\
\hline Hayır & $f$ & $\%$ & $f$ & $\%$ \\
Evet & 222 & 84.09 & 207 & 83.13 \\
\hline
\end{tabular}

Tablo 10' a göre 7. sınıf öğrencilerinden 222 öğrenci akrabaları ya da yakın çevresinde organ bağışında bulunanların olmadığını, 40 öğrenci akrabaları ya da yakın çevresinde organ bağışında bulunanların olduğunu belirtilirken, 8. sınıf öğrencilerinden 207 öğrenci akrabaları ya da yakın çevresinde organ bağışında bulunanların olmadığını, 39 öğrenci ise akrabaları ya da yakın çevresinde organ bağışında bulunanların olduğunu belirtilmiştir. 7. sınıf öğrencilerinden 2 öğrenci ve 8. sınıf öğrencilerinden 3 öğrenci de soruyu yanıtsız bırakmıştır. Genel olarak 7. ve 8.sınıf öğrencilerinin akraba ya da çevresinde organ bağışında bulunan kişilerin az olduğu görülmektedir.

Dokuzuncu sorudan itibaren öğrencilerin organ bağışı ve nakline yönelik görüşleri ile ilgili sorular sorulmuş ve yanıtları alınmıştır. 9. soruda öğrencilere ileride organ bağışında bulunmayı düşünüyor musunuz diye sorulmuştur. Verilen yanıtlar Tablo 11'de belirtilmiştir.

Tablo 11

Organ Bağışında Bulunma İsteğ $i$

\begin{tabular}{lcccc}
\hline & \multicolumn{2}{c}{ 7. Sını Öğrencileri } & \multicolumn{2}{c}{ 8. Sinıf Öğrencileri } \\
\hline Fikrim yok & $f$ & $\%$ & $f$ & $\%$ \\
Evet & 125 & 47.35 & 116 & 46.59 \\
Hayır & 115 & 43.56 & 105 & 42.17 \\
\hline
\end{tabular}

Tablo 11 incelendiğinde her iki gruptaki öğrencilerin büyük çoğunluğunun ileride organ bağışında bulunmak için şuan fikirlerinin olmadığını ifade ettikleri görülmektedir. Organlarını bağışlamak isteyen ve istemeyen öğrenci sayılarının ise iki grupta da birbirine yakın olduğu görülmektedir. Ayrıca organ bağışında bulunmak isteyen öğrencilerin sayısının organ bağışında bulunmak istemeyenlere oranla daha fazla olduğu dikkat çekmektedir.

Onuncu soruda öğrencilere ailelerinden bir kişiye organ nakli yapılması gerektiği ve bu kişinin dokularının da sadece kendi dokularıyla uyuştuğu varsayımı söylenmiştir. Böyle durumda organlarını bağışlamak isteyip istemeyecekleri sorulmuştur. Verilen yanıtlar Tablo 12'de belirtilmiştir. 
Tablo 12

Öğrencilerin Ailesinden Bir Kişiye Organ Bağışında Bulunma İstekleri

\begin{tabular}{lcccc}
\hline & \multicolumn{2}{c}{ 7. Sinıf Öğrencileri } & \multicolumn{2}{c}{ 8. Sinıf Öğrencileri } \\
\hline \multirow{2}{*}{ Evet } & $f$ & $\%$ & $f$ & $\%$ \\
Hayır & 242 & 91.67 & 229 & 91.97 \\
& 21 & 7.95 & 17 & 6.83 \\
\hline
\end{tabular}

Tablo 12 incelendiğinde genel olarak 7. ve 8. sınıf öğrencilerinin ailesinden birine organ nakli gerektiğinde, organlarını bağışlamak isteyenlerin çoğunlukta olduğu görülmektedir. 7. sınıf öğrencilerinden 1 öğrenci, 8. sınıf öğrencilerinden ise 3 öğrenci soruyu yanıtsız bırakmıştır.

Onbirinci soruda öğrencilere tanımadıkları bir kişiye organ nakli yapılması gerektiği ve bu kişinin dokularının da sadece kendi dokularıyla uyuştuğu varsayımı söylenmiştir. Böyle durumda organlarını bağışlamak isteyip istemeyecekleri sorulmuştur. Verilen yanıtlar Tablo 13'te belirtilmiştir.

Tablo 13

Öğrencilerin Tanımadı̆̆ı Bir Kiş̧iye Organ Bă̆ışında Bulunma İstekleri

\begin{tabular}{lcccc}
\hline & \multicolumn{2}{c}{ 7. Sını Öğrencileri } & \multicolumn{2}{c}{ 8. Sinıf Öğrencileri } \\
\hline Evet & $f$ & $\%$ & $f$ & $\%$ \\
Hayır & 161 & 60.98 & 164 & 65.86 \\
& 103 & 39.02 & 78 & 31.32 \\
\hline
\end{tabular}

Tablo 13 incelendiğinde tanımadığı kişilerin organ nakline ihtiyacı olduğunda, 7. ve 8. sinıflardan organ bağışında bulunmak isteyen öğrencilerin çoğunlukta olduğu ve organlarını bağışlamak isteyen 8. sınıf öğrencilerinin (\%65.86), 7. sınıf öğrencilerinden (\%60.98) fazla olduğu görülmektedir.

Onbirinci sorunun devamında tanımadığı kişilere organlarını vermek isteyen öğrencilerin, organlarını bağışlamaları karşılı̆̆ında herhangi bir bedel istemeleri sorulmuştur. Verilen yanıtlar Tablo 14'te belirtilmiştir.

Tablo 14

Öğrencilerin Organları Bă̆ışlama Karşılı̆̆ında Herhangi Bir Bedel Talep Etmeleri

\begin{tabular}{lcccc}
\hline & \multicolumn{2}{c}{ 7.Sinıf Öğrencileri } & \multicolumn{2}{c}{ 8.Sınıf Öğrencileri } \\
\hline & $f$ & $\%$ & $f$ & $\%$ \\
\hline Hayır & 148 & 91.93 & 154 & 93.90 \\
Evet & 13 & 8.07 & 10 & 6.10 \\
\hline
\end{tabular}

Tablo 14'e göre organlarını tanımadığı kişilere bağışlamak isteyen 7. sınıf öğrencilerinden $(n=161) 148$ öğrenci, tanımadığı bir kişinin organ nakline ihtiyacı 
olduğunda organlarını bağışlama karşılığında herhangi bir bedel istemezken, 13 öğrenci istemektedir. Organlarını tanımadığı kişilere bağışlamak isteyen 8. sınıf öğrencilerinden ( $\mathrm{n}=164) 154$ öğrenci, tanımadığı bir kişinin organ nakline ihtiyacı olduğunda organlarını bağışlama karşılığında herhangi bir bedel istemezken 10 öğrenci istemektedir. Genel olarak 7. ve 8. sınıf öğrencilerinin tanımadıkları kişilere organlarını bağışlama karş1lığında herhangi bir bedel istemedikleri görülmektedir.

Onikinci soruda öğrencilere organ nakli ve organ bağışının dini açıdan sakıncalı olma durumu sorulmuştur. Verilen yanıtlar Tablo 15'te belirtilmiştir.

Tablo 15

Organ Bağışı ve Organ Naklinin Dini Açıdan Sakıncalı Olma Durumu

\begin{tabular}{lcccc}
\hline & \multicolumn{2}{c}{ 7. Sını Öğrencileri } & \multicolumn{2}{c}{ 8. Sinıf Öğrencileri } \\
\hline & $f$ & $\%$ & $f$ & $\%$ \\
\hline Hayır & 247 & 93.56 & 236 & 94.78 \\
Evet & 17 & 6.44 & 12 & 4.82 \\
\hline
\end{tabular}

Tablo 15'e göre 7. sınıf ve 8. sınıf öğrencilerinin çoğunluğunun organ bağışının dini açıdan uygun olduğunu, az bir kısmının organ bağışının dini açıdan uygun olmadığını belirttiği görülmektedir. Genel olarak 7. ve 8. sınıf öğrencileri organ bağışını dini açıdan sakıncalı görmemektedirler. Öğrencilerin organ bağışı ve organ naklinin dini açıdan sakıncalı olup olmadığına ilişkin görüşlerinden örnekler aşağıda sunulmuştur:

'Hayır düşünmüyorum. Birisine can veriyoruz, niçin günah olabilir ki' (Öğrenci-5)

'Bağışladığımız organlar ile ölürüz, cennete gideriz ve bunun için dini açıdan sorun olmaz' (Öğrenci-96)

'Dini açıdan sakınca yok. Bunu belirten bir kural yok çünkü’ (Öğrenci-307)

\section{Sonuç ve Tartışma}

Çalışmada ortaokul 7. ve 8. sınıf öğrencilerinin organ bağışı ve organ nakli hakkında bilgilerinin ve tutumlarının incelenmesi amaçlanmıştır. Yapılan çalışmada organ bağışı ve nakli konusundaki bilgilerini 7. sınıf öğrencileri en çok öğretmenden (\%61.74) edindiklerini belirtirken, 8. sinıf öğrencileri internetten (\%52.21) ve öğretmenden (\%51.41) edindiklerini belirtmişlerdir. 7. sınıf öğrencileri organ bağış1 konusunu dönem içerisinde fen bilimleri dersindeki ünite kazanımlarında işlediklerinden en çok öğretmenden bilgi edindikleri ve internet kullanımının günümüzde yaygın hale gelmesinden dolayı 8. sınıf öğrencilerinin internetten bilgi edindikleri düşünülmektedir. Bu bulgu alanyazında farklı örneklem grupları ile yapılan çalışma sonuçları ile örtüşmektedir. Örneğin; Özer Gök vd. (2008) üniversite öğrencileri ile yaptıkları çalışmada öğrencilerin bilgilerini okulda derslerden, seminerlerden (\%73.60) edindiklerini belirterek benzer sonuçlar bulmuşlardır. Bunun yanında Vicdan vd., (2011) yüksekokul öğrencileri ile yaptıkları çalışmada öğrencilerin organ bağışı ile ilgili bilgilerini \%46.90 radyo ve TV'den, \%32.00 ders kitaplarından edindiklerini, Uzuntarla (2016) lise öğrencileriyle yaptığı çalışmada öğrencilerin organ bağışı ile ilgili bilgilerini internetten (\%46.90) ve TV'den (\%16.80), Çetin ve Harman (2012) ise lise 
öğrencileri ile yaptıkları çalışmada öğrencilerin organ bağışı ile ilgili bilgilerini internetten (\%36.00), TV'den (\%44.00) ve okuldan (\%30.00) edindiklerini belirtmiştir.

Araştırmada organ bağışında bulunabilecek birimler olarak 8. sınıf öğrencilerinin en s1k tekrar ettiği yanıtlar, devlet hastaneleri (\%59.84) ve üniversite hastaneleri (\%56.63) olarak bulunurken, Uzuntarla'nın (2016) lise öğrencileriyle yaptı̆̆ çalışmada en sık tekrar edilen yanıt kamu ve üniversite hastaneleri (\%97.30) olarak ve Çetin ve Harman'ın (2012) lise öğrencileriyle yaptıkları çalışmada en sık tekrar edilen yanitlar devlet hastaneleri (\%48.00) ve üniversite hastaneleri (\%74.00) olarak bulunmuştur. Çalışmada organ bağışında bulunabilme şartları olarak en sık tekrar edilen yanıtlar, 7. sınıf öğrencilerinde sağlık raporu (\%81.44) ve nüfus bilgilerini içeren kimlik (\%64.39), 8. sinıf öğrencilerinde sağlık raporu (\%87.55) ve nüfus bilgilerini içeren kimlik (\%64.66) olarak bulunurken Çetin ve Harman'ın (2012) lise öğrencileri ile yaptıkları çalışmada sağlık raporu (\%80.00) ve nüfus bilgilerini içeren kimlik (\%64.00) olarak bulunmuş ve benzer sonuçlar göstermiştir. Akış vd.'nin (2008) üniversite personeliyle yaptıkları çalışmada ise bu oran sağlık raporu (\%38.92) ve nüfus bilgilerini içeren kimlik (\%31.54) olarak bulunmuştur. Öğrencilerin en sik sağlik raporunu belirtmelerinin nedeni olarak bir işe girilirken, o iş için sağlık durumunun elverişli olup olmadığının tespit edilmesi amacı ile bireylerden sağlık raporu istenildiğinden organ bağışında bulunmak için de sağlık raporu olursa organları bağışlamak için bir engel olmadığı kanısında oldukları düşünülmektedir. Organ bağışı için doku uyumu gerekli midir sorusuna yönelik bulgularda 7. sınıf öğrencilerinin \%94.32'si, 8. sinıf öğrencilerinin \%93.57'si organ bağışı için doku uyumu gerektiğini belirtirken Uzuntarla'nın (2016) lise öğrencileriyle yaptığı çalışmada öğrencilerin \%91.00'i, Çetin ve Harman'ın (2012) lise öğrencileri ile yaptıkları çalışmada öğrencilerin \%96.00's1 organ bağışı için doku uyumu gerektiğini belirtmişlerdir ve yapılan çalışmayla benzer sonuçlar bulunmuştur. Akış vd.'nin (2008) üniversite personeliyle yaptığı çalışmada bu oran \%70.00 olarak bulunmuştur. Çalışmada organ bağışında bulabilmek için gerekli şartları, 7. sınıf öğrencilerinin çoğunluğu beyin ölümü (\%62.12) ve birinci derece iki yakınının onayı (\%56.82), 8. sınıf öğrencilerinin çoğunluğu beyin ölümü (\%58.63) ve doktor onayı (\%57.83) olarak belirtirken, Çetin ve Harman'ın (2012) lise öğrencileriyle yaptıkları çalışmada öğrenciler birinci derece yakını onayı (\%82.00), doktor onayı (\%46.00) ve beyin ölümü (\%44.00) olarak belirtmişlerdir. Akış vd.'nin (2008) üniversite personeliyle yaptıkları çalışmada ise birinci derecede akraba onayı (\%47.40) ve beyin ölümü (\% 31,85) olarak belirtilmiştir.

Çalışmada bağışlanabilen organların tamamını (böbrek, akciğer, karaciğer, kalp, kalp kapağı, kornea, ince bağırsak ve pankreas) 7. sınıf öğrencilerinin \%60.98'i, 8. sınıf öğrencilerinin \%36.55'i belirtirken, Çetin \& Harman'ın (2012)' in lise öğrencileriyle yaptıkları çalışmada öğrencilerin tamamı $(\% 100,00)$, Vicdan vd.'nin (2011) üniversite öğrencileri ile yaptıkları çalışmada öğrencilerin \%44.70’i belirtmiş̧tir. Yapılan çalışmada öğrencilerin çoğunluğunun böbrek ve karaciğeri bağışlanabilen organ olarak belirtmelerinin nedeni televizyonlarda, haberlerde böbrek ve karaciğer naklinin sıksık gündeme gelmesinden olabilir. Akrabasından ya da yakın çevresinden organ bağışında bulunanların oranı çalışmada 7. sınıf öğrencileri \%15.15, 8. sınıf öğrencileri \%15.66 olarak bulunmuştur. Bu oran Akış vd.'nin (2008) üniversite personeliyle yaptıkları çalışmada \%8.00 olarak bulunmuştur. Organ bağışında bulunmak isteyenlerin oranı, çalışmada 7. sınıf öğrencilerinde $\% 43.56$ ve 8 . sınıf öğrencilerinde $\% 42.17$ olarak 
bulunmuştur. Bu oran Aytaş vd.'nin (2012) hemşirelerle yaptıkları çalışmada \%42.00 bulunarak benzer sonuç gösterirken, Çetin ve Harman'ın (2012) lise öğrencileri ile yaptıkları çalışmada \%12.00, Uzuntarla'nın (2016) lise öğrencisiyle yaptığı çalışmada $\% 60.00$ olarak bulunmuştur. Üniversite öğrencileri ile yapılan çalışmalarda bu oran Yaşar vd., (2008) \%34.90, Vicdan vd., (2011) \%51.80, Özer Gök vd., (2008) \%71.70, Kılıç, Koçak, Türker, Gürpınar ve Gülerik, (2010) \%91.10 olarak bulunmuştur. Akış vd.'nin (2008) üniversite personeliyle yaptıkları çalışmada ise \%21.00 olarak bulunmuştur. Ailesinden bir kişiye organ bağışında bulunma isteği olarak, yapılan çalışmada 7. sınıf öğrencileri \%91.67, 8. sınıf öğrencileri \%91.97 olumlu görüş belirtmişlerdir. Özer Gök vd.'nin (2008) üniversite öğrencileriyle yaptıkları çalışmada bu oran \%98.10 bulunarak benzer sonuç göstermiştir. Çetin ve Harman'1n (2012) lise öğrencileriyle yaptıkları çalışmada ise öğrencilerin \%56.00'sı olumlu görüş belirtmişlerdir. Tanımadığı kişiye organ bağışında bulunma isteği olarak çalışmada 7 . sınıf öğrencilerinin \%39.20'si, 8. sınıf öğrencilerinin \%31.32'si olumlu görüş belirtmişlerdir. Organlarını tanımadıkları kişilere bağışlamada olumlu görüş belirten 7 . sınıf öğrencilerinin \%91.93'ü ve 8. sınıf öğrencilerinin \%93.90’1 organlarını bağışlama karşılığında bedel talep etmemektedir. Çetin ve Harman (2012), lise öğrencileriyle yaptıkları çalışmada öğrencilerin \%96.00’sının, Sungur ve Mayda (2014), tıp fakültesi öğrencileriyle yaptıkları çalışmada 1. dönem öğrencilerinin \%6910'unun ve 6. dönem öğrencilerinin \%88.90'ının organ bağışı karşılığında herhangi bir bedel talep etmediğini rapor etmişlerdir. Çalışmada 7. sınıf öğrencilerinin \%93.56's1 ve 8. sınıf öğrencilerinin \%94.78'si organ bağışının dini yönden sakıncalı olmadığını belirtmişlerdir. Uzuntarla'nın (2016) lise öğrencileriyle yaptığı çalışmada öğrencilerin \%80.50’ i, Özer Gök vd.'nin (2008) sağlık yüksekokulu öğrencileri ile yaptıkları çalışmada öğrencilerin \%84.90' u, Sungur ve Mayda (2014), tıp fakültesi öğrencileriyle yaptıkları çalışmada 1. dönem öğrencilerinin \%72.80’i ve 6. dönem öğrencilerinin \%84.40’1 organ bağışının dini yönden sakıncalı olmadığını belirtmişlerdir. Çetin ve Harman (2012) lise öğrencileriyle yaptıkları çalışmada bu oranı \%43.00, Aytaş vd., (2011) ise hemşirelerle yaptıkları çalışmada \%49.50 olarak belirtmişlerdir. Bunun bireylerin inançlarından kaynaklandığı düşünülmektedir. Yani bazı öğrenciler organ bağışı ve naklinin yapılmasını dinen uygun olmadığını düşünürken, bazıları da herhangi bir sakıncasının olmadığını belirtmektedirler. $\mathrm{Bu}$ da inancın tutum üzerinde etkisi olduğunu göstermektedir (Baysal, 1981, akt. Tavşanc1l, 2014).

Çalışmada ortaokul öğrencilerin organ bağışı ve organ nakline yönelik görüşlerinin lise öğrencilerininkinden daha olumlu olduğu görülmektedir. Bunun, sosyobilimsel konuların hem ortaokul fen bilimleri öğretim programında (MEB, 2018a) hem de biyoloji dersi öğretim programının özel amaçları içerisinde (MEB, 2018b) yer almasına rağmen, ortaokul fen bilimleri öğretim programında organ bağışı ve nakli konusunun, duyu organlarımız konusu içerisinde ayrı bir başlık halinde verilerek öğrencilerin bu konularda bilgi edinmelerinden ve edindikleri bilgiler sayesinde görüşlerinin daha net, açık ve olumlu olduğundan kaynaklandığı düşünülmektedir.

\section{Öneriler}

Araştırmada elde edilen bulgulardan yola çıkılarak şu önerilerde bulunulabilir:

- Organ bağışı ve organ nakli konusu öğrencilere anlatılırken öğretmenler konuları farklı öğretim yöntem ve teknikleri ile işleyebilirler. 
- 8.sınıfta din kültürü ve ahlak bilgisi dersinde organ bağışı ile ilgili doğrudan konu olmamasına rağmen 4. ünite olan Kur'an da Akıl ve Bilgi ve 6. ünite olan Dinler ve Evrensel Öğütleri konuları işlenirken din kültürü ve ahlak bilgisi öğretmenleri organ bağışının önemine değinebilirler.

- Ülkemizde Kasım ayında düzenlenen Organ ve Doku Bağışı Haftası kapsamında okullarda çeşitli etkinlikler düzenlenerek 7 ve 8 . sınıf öğrencileri arasındaki organ bağışı ve organ nakli bilgi düzeyleri farklılıkları giderilebilir ve öğrenciler daha bilgili ve bilinçli olabilirler.

- Bu konuyla ilgili ortaokul düzeyinde yapılacak çalışmalar arttırılabilir.

- Daha büyük örneklem gruplarıyla bir ildeki birkaç farklı ilçede ya da bir bölgedeki birkaç farklı ilde araştırmalar yapılması da önerilmektedir. 


\section{Summary}

Purpose and Significance: Science and society have always been interaction with each other (Topçu, 2015). The rapid developments in science and technology have effects the society in positive and negative ways. There are a lot of scientific issues (organ transplantation, three parent babies, genetic, etc.) that can be argue in daily life. Individuals who are aware of these issues are called scientifically literated person. One of the significant aims of science education is to contribute students' scientific literacy.

Some science issues are directly related with daily life. Organ donation; which can be frequently seen on newspapers, internet, and television are one of those issues. Thus, this study aims to investigate individuals' views about organ donation and transplantation issue.

Organ donation is the consent of someone by their free-will to donate their organs when they die. (Organ Transplantation Cordination Council [Onkod], 2017). If the person has not donated his organs before his death and his organs have not lost their functioning before brain death, specialists may receive donations by requesting consent form from their first degree close relatives. Organ transplantation is medical process that involves removing an organ from one body and placing in the body of a recipient to replace a missing organ. The organs to be transplanted can be removed from donors who may be living or may have died of brain death (Sungur \& Mayda, 2014). Today, the following organs can be transplanted: lung, liver, small intestine, heart, cardiac valve, pancreas, kidney, bone marrow, cornea (Bölükbaş, Eyüpoğlu, \& Kurt, 2004).

Organ donation and organ transplant are included in the 7th grade science curriculum (M.E.B., 2013) and $6^{\text {th }}$ grade science curriculum (MEB, 2018a). The program aims to provide students with sufficient information on organ donation and to raise the importance of organ donation in terms of social solidarity. This research aims to investigate the knowledge levels and opinions of secondary school level students about organ donation. It aspires to explore differences between 7th and 8th grade students' knowledge levels and opinions in terms of organ donation and organ transplantation

Methods: This research employs a survey method of quantitative methodology, which aims to identify the views or interests and skills of the participants (Fraenkel \& Wallen, 2006). It draws from the survey model that describes a situation at a given time (Karasar, 2017). The research uses convenient sampling that save time and money (Büyüköztürk, Çakmak, Akgün, Karadeniz, \& Demirel, 2016). The population of the study is $5617^{\text {th }}$ and $8^{\text {th }}$ grade of students (292 $7^{\text {th }}$ grade and $2698^{\text {th }}$ grade) students studying at a public school in Aydin (Turkey) during the first semester of 2017-2018 academic year. The participants are $5137^{\text {th }}$ and $8^{\text {th }}$ grade students $(264$ girls and 249 boys) in Kuyucak province of Aydin. A questionnaire consisting of 7 questions about personal demographics and 12 questions eliciting the views on organ donation and transplantation were used. Expert opinions was taken if Organ Donation Information Questionnaire consisting of 12 questions and developed by Akış et. al. (2008) is eligible to be used in a study with $7^{\text {th }}$ grade students.

Results: Results show that $7^{\text {th }}$ grade students mostly get information about organ donation from their teachers $(61.74)$, however, $8^{\text {th }}$ grade students get information about 
organ donation from internet $(52.21 \%)$ and their teachers $(51.41 \%)$. It is thought that $7^{\text {th }}$ grade students get information about organ donation from their teacher because they learn the subject during the science course. However, 8th grade students get information from the internet because internet usage becomes widespread nowadays and the organ donation is not part of $8^{\text {th }}$ grade science topics. In the study, the most frequently repeated responses of $8^{\text {th }}$ grade students in terms of institutions for donation is public hospitals (59.84\%) and university hospitals (56.63\%). Likewise, in Uzuntarla's (2016) research, the most frequently repeated responses for high school students is public and university hospitals $(97.3 \%), 60.98 \%$ of $7^{\text {th }}$ grade students and $36.55 \%$ 8th grade students stated that all organs (kidney, lung, liver, heart, cardiac valve, cornea, small intestine and pancreas) can be donated.

Discussion and Conclusions: In this research, it was found that 7 the and $8^{\text {th }}$ grade students had different levels of knowledge on organ donation and organ transplantation but their opinions were generally the same. It is thought that these differences occur because $8^{\text {th }}$ grade science curriculum does not include topic of organ donation. Therefore, students forget the knowledge they learned in $7^{\text {th }}$ grade on about organ donation and organ transplantation. While organ donation and organ transplantation are taught to the students, teachers can handle the subjects with different teaching methods and techniques. Although there is no mention of organ donation in religion, culture and ethics course in the $8^{\text {th }}$ grade, $4^{\text {th }}$ unit of the course on Mind and Knowledge in the Qur'an and $6^{\text {th }}$ unit on Religions and Universal Lessons can address the importance of organ donation. Various events can be organized at school within the scope of Organ and Tissue Donation Week in November in order to raise awareness and improve knowledge on organ donation. Thus, differences in knowledge level of organ donation and transplantation between $7^{\text {th }}$ and $8^{\text {th }}$ grade students can be minimized. It is also suggested that further studies can be conducted on this topic with larger sample groups and in different provinces. 


\section{Kaynakça}

Akçöltekin, A. (2014). Sınıf öğretmenlerinin organ bağışı tutumlarının farklı değişkenler açısından incelenmesi. Karadeniz Uluslararası Bilimsel Dergi, 6, 5263.

Akış, M., Katırcı, E., Uludağ, H. Y., Küçükkılıç, B., Gürbüz, T., Türker, Y., \& Gül, H. (2008). Süleyman Demirel Üniversitesi personelinin organ-doku bağışı ve nakli hakkındaki bilgi ve tutumları. S.D. Ü. Tıp Fakültesi Dergisi, 15(4), 28-33.

Aytaş, Ö., Kartalcı, Ş., \& Ünal, S. (2011). Bir grup hemşirenin sosyodemografik verileri ve tükenmişlik düzeyleri bağlamında organ bağışına bakış açıları. İnönü Üniversitesi Tıp Fakültesi Dergisi, 18(1), 26-32.

Balcı, E., \& Şahingöz, M. (2014). Hemşirelerin organ bağışına bakışları. Cumhuriyet Medical Journal, 36(4), 503-511.

Baykan, Z., Naçar, M., Yamanel, R., Uzun, A., Dağlıtuncezdi, Ş., Davran, H. \& Murt, G. (2009). Tıp Fakültesi birinci sınıf öğrencilerinin organ-doku nakli konusundaki bilgi, tutum ve davranışları. Ulusal Cerrahi Dergisi [Turkish Journal of Surgery], 25(4), 137-141.

Bedi, K. K., Hakeem, A. R., Dave, R., Lewington, A., Sanfey, H., \& Ahmad, N. (2015). Survey of the knowledge, perception, and attitude of medical students at the University of Leeds toward organ donation and transplantation. Transplantation Proceedings, 47(2), 247-260.

Bölükbaş, N., Eyüpoğlu, A., \& Kurt, P. (2004). Organ bağışı hakkında üniversite öğrencilerinin düşünceleri. O.M.Ü. Tip Dergisi, 21(2), 73-77.

Burra, P., De Bona, M., Canova, D., D'Aloiso, M. C., Germani, G., Rumiati, R., ... \& Ancona, E. (2005). Changing attitude to organ donation and transplantation in university students during the years of medical school in Italy. Transplantation Proceedings, 37(2), 547-550.

Büyüköztürk, Ş., Çakmak, K. E., Akgün, Ö. E., Karadeniz, Ş., \& Demirel, F. (2016). Bilimsel araştırma yöntemleri (22. bas.). Ankara: Pegem Akademi Yayıncılık.

Çetin, G., \& Harman, Ö. (2012). Lise öğrencilerinin organ nakli ve bağışı konusundaki bilgi ve tutumları. Eğitim ve Öğretim Araştırmaları Dergisi, 1(2), 172-177.

Demir Doğan, M., Uzun, İ., Kaya, N., Ekinci, H., \& Altınkaynak, M. (2016). Üniversite öğrencilerinin organ bağışına bakış açısı ve bilgi düzeyleri. Sağlık Bilimleri ve Meslekleri Dergisi, 3(2), 99-105.

Efil, S., Şişe, Ş., Üzel, H., \& Eser, O. (2013). Afyon İlindeHalkın Ve Afyon Kocatepe Üniversitesi TıpFakültesi Sağlık Çalışanlarının Organ BağışıKonusuna İlgilerinin Değerlendirilmesi. Gümüşhane Üniversitesi Sağllk Bilimleri Dergisi, 2(3), 361-384.

Fraenkel, J. R., \& Wallen, N. E. (2006). How to design and evaluate research in education. (6th ed.). New York: McGraw-Hill International Edition.

Genç, M., \& Genç, T. (2017). Türkiye'de sosyo-bilimsel konular üzerine yapılmış araştırmaların içerik analizi. Kafkas Eğitim Araştırmaları Dergisi, 4(2), 19-26.

Güler, S., Yava, A., Karakaş Doğan, S., \& Perim Ketenciler, A. (2017). Bir üniversite öğrencilerinin organ bağıșı hakkındaki bilgi ve düşünceleri. Adıyaman Üniversitesi Să̆lık Bilimleri Dergisi, 3(1), 418-433. 
Harman, G., \& Çökelez, A. (2017). Fen bilgisi öğretmen adaylarının sosyo-bilimsel bir konu olan organ bağışına yönelik metaforik algıları. Uşak Üniversitesi Sosyal Bilimler Dergisi, 10(1), 55-70.

Kara, S., Salman, Z., \& Öngel, K. (2012). Süleyman Demirel Üniversitesi Tıp Fakültesi sağlık personelinin organ bağışına bakışı. Ankara Sağlık Hizmetleri Dergisi, 11(1), 33-9.

Karasar, N. (2017). Bilimsel araştırma yöntemi (32.bas.). Ankara: Nobel Yayınları.

Kavurmac1, M., Karabulut, N., \& Koç, A. (2014). Üniversite öğrencilerinin organ bağgşı hakkındaki bilgi ve görüşleri. Hemşirelikte Eğitim ve Araştırma Dergisi, 11(2), 1521.

Kılıç, S., Koçak, N., Türker, T., Gürpınar, H., \& Gülerik, D. (2010). Kız üniversite öğrencilerinin organ bağışı konusundaki tutumları ve bu tutumlarına etki eden faktörler. Gülhane Tip Dergisi, 52, 36-40.

Koçak, A., Aktaş, E. Ö., Şenol, E., Kaya, A., \& Bilgin, U. E. (2010). Ege Üniversitesi Tıp Fakültesi öğrencilerinin organ nakli ve bağışı hakkındaki bilgi düzeyi. Ege Tıp Dergisi, 49(3), 153-160.

Liu, H., Peng, X., Zhang, S., Qiao, X., \& Hao, Y. (2015). Posthumous organ donation beliefs of college students: a qualitative study. International Journal of Nursing Sciences, 2(2), 173-177.

Miles, M. B., \& Huberman, A. M. (1994). Qualitative Data Analysis: An Expanded Sourcebook. (2nd Ed.). California: Sage Publications.

Milli Eğitim Bakanlığı (MEB) (2013). İlköğretim Kurumları Fen Bilimleri Dersi (3, 4, 5, 6, 7 ve 8. Sınıflar) Öğretim Programı. Ankara.

Milli Eğitim Bakanlığı (MEB) (2018a). Fen Bilimleri Dersi (İlkokul ve Ortaokul 3, 4, 5 , 6, 7 ve 8. Sinıflar) Öğretim Programı. Ankara.

Milli Eğitim Bakanlığı (MEB) (2018b). Ortaöğretim Biyoloji Dersi (9, 10, 11 ve 12. Sınıflar) Öğretim Programı. Ankara.

Organ Nakli Koordinatörleri Derneği. 24.11.2017 tarihinde http://www.onkod.org.tr/sayfa-grubu/organ-doku-hucre-bagisi-ve-nakli/5 adresinden erişilmiştir.

Öz, F., Ayranc1, Ü., Arslantaş, D., \& Ünsal, A. (2016). Bir grup Türk ortaokulu ve lise öğrencilerinin organ ve doku bağışı bilgi düzeyi. TAF Preventive Medicine Bulletin, 15(6), doi: 10.5455/pmb.1-1435753377

Özer Gök, F., Karamanoğlu Yavuz, A., Beydağ, K. D., Fidancıoğlu, H., Akıncı, E., Şanlı, İ., \& Urak, S. (2008). Pamukkale Üniversitesi Denizli Yüksek Okulu'nda öğrenim gören bir grup öğrencinin organ nakli ve bağışına yönelik görüşleri ve bilgi düzeylerine eğitimin etkisi. TSK Koruyucu Hekimlik Bülteni, 7(1), 39- 46.

Özmen, D., Çetinkaya, A.C., Sarızeybek, B., \& Zeybek, A. (2008). C.B.Ü Manisa Sağlık Yüksekokulu öğrencilerinin organ bağışına ilişkin bilgi ve görüşleri [Knowledge and views of stu-dents of the Celal Bayar University Manisa School of Health towards organ donation]. Türkiye Klinikleri [J Med Sci], 28(3), 311-318.

Özpulat, F. (2017). Üniversite öğrencilerinin kan ve organ bağışına ilişkin düşünceleri. Să̆llk Bilimleri ve Meslekleri Dergisi, 4(2), 71-79. 
Siebelink, M. J., Geerts, E. A., Albers, M. J., Roodbol, P. F., \& van de Wiel, H. B. (2011). Children's opinions about organ donation: A first step to assent?. The European Journal of Public Health, 22(4), 529-533.

Sungur, M. A., \& Mayda, A. S. (2014). Düzce Üniversitesi Tıp Fakültesi dönem I ve dönem VI öğrencilerinin organ bağışı konusunda bilgi ve tutumları. Düzce Üniversitesi Sağlık Bilimleri Enstitüsü Dergisi, 4(2), 15-20.

Tarhan, M., Dalar, L., Yıldırımoğlu, H., Sayar, A., \& Altın, S. (2012). Zeytinburnu İlçesi' nde lise son sınıfta öğrenim gören öğrencilerin organ nakli ve bağışına yönelik bilgi düzeyleri ve tutumlarına bilgilendirmenin etkisi. Yoğun Bakım Dergisi, 3, 27-35.

Tavşancıl, E. (2014). Tutumların ölçülmesi ve SPSS ile veri analizi (5.Baskı), Ankara: Nobel Akademik Yayıncılık.

Topçu, M. S. (2015). Sosyobilimsel konular ve öğretimi, Ankara: Pegem Akademi.

Uzuntarla, Y. (2016). Genç yaş grubunun organ bağışına yönelik düşünce ve bilgi düzeylerinin verilen eğitime göre karşılaştırılması. Türk Nefroloji Diyaliz ve Transplantasyon Dergisi, 25(3): 296-301. doi: 10.5262/ tndt.2016.1001.20

Vicdan, K. A., Peker, S., \& Üçer, B. (2011). Akşehir Sağl1k Yüksekokulu öğrencilerinin organ bağışı ile ilgili tutumlarının belirlenmesi. TAF Preventive Medicine Bulletin, 10(2), 175-180.

Yaşar, M., Oğur, R., Uçar, M., Göçgeldi, E., Yaren, H., Tekbaş, Ö. F., \& Korkmaz, A. (2008). Bir Sağlık Meslek Yüksekokulu son sınıf öğrencilerinin organ bağış1 konusundaki tutumları ve tutumlarına etki eden faktörler. Genel Tip Dergisi, 18(1), 33-37. 